\title{
Multifocal Langerhans Cell Histiocytosis in an Adult
}

\author{
Shoji Hirasaki ${ }^{1,2}$, Kazutoshi Murakami ${ }^{1}$, Takaaki Mizushima ${ }^{1}$ and Norio Koide ${ }^{1,2}$
}

Key words: eosinophilic granuloma, bone involvement, pituitary involvement, diagnostic imaging

(Intern Med 51: 119-120, 2012)

(DOI: 10.2169/internalmedicine.51.6630)

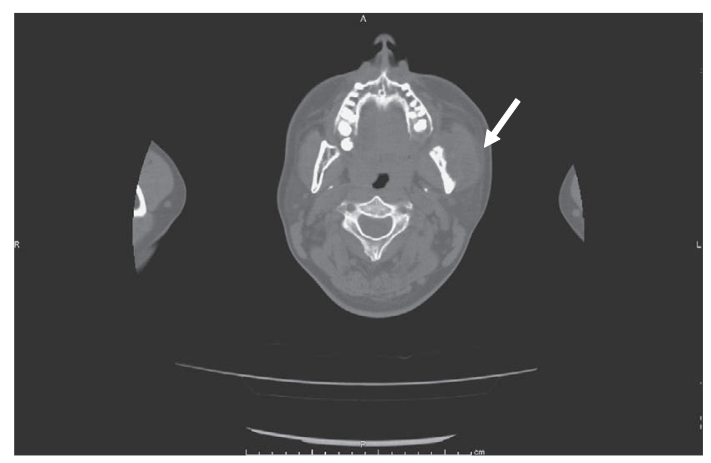

Picture 1.

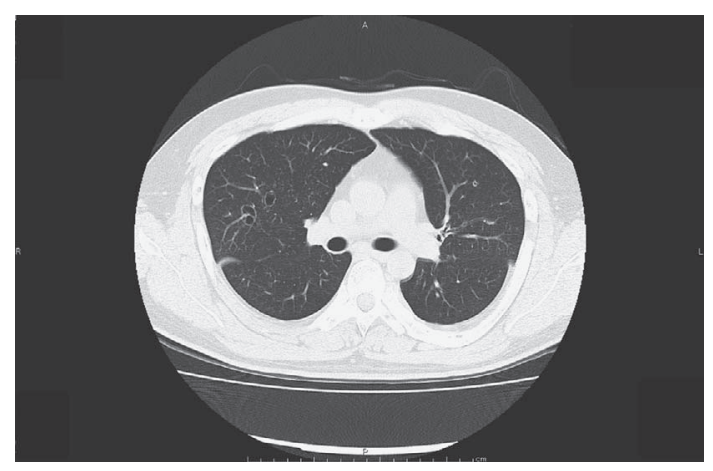

Picture 2.

A 30-year-old man visited our hospital complaining of the left lower jaw swelling. The past history of cranial bone disease and thoracic vertebra lesion led to the diagnosis of Langerhans cell histiocytosis (LCH) 8 years previously. A head computed tomography (CT) showed a bone lesion in the left ramus of the mandible spreading into the adjacent masseter and temporal muscle (Picture 1). A chest CT demonstrated multiple cystic structures predominat in the upper lobes (Picture 2). Bone scintigraphic study identified uptake of ${ }^{99 \mathrm{~m}} \mathrm{Tc}$-methylene diphosphonate in the left mandible, left rib 7, thoracic vertebra, and ilium, etc (Picture 3). Magnetic

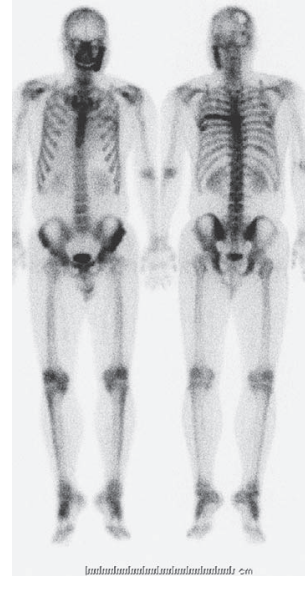

Picture 3.

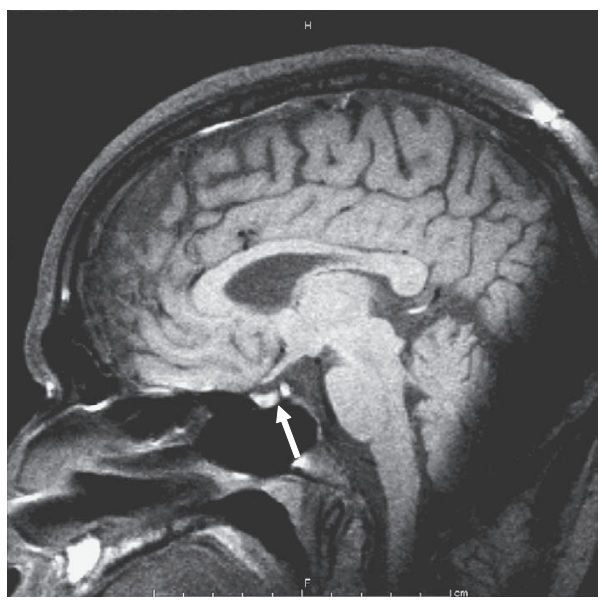

Picture 4.

resonance imaging showed the absence of the normal posterior pituitary bright spot (Picture 4). He was treated with prednisolone; however, the clinical course was unfavorable. $\mathrm{He}$ is now undergoing chemotherapy (vinblastine-

${ }^{1}$ Department of General Medicine, Okayama University Graduate School of Medicine, Dentistry, and Pharmaceutical Sciences, Japan and ${ }^{2}$ Department of Internal Medicine, Kousei Hospital, Japan

Received for publication September 27, 2011; Accepted for publication October 11, 2011

Correspondence to Dr. Shoji Hirasaki, s.hirasaki@kousei-hp.or.jp 
prednisolone-6-mercaptopurine) (1). $\mathrm{LCH}$ in adults is extremely rare (1) and multifocal $\mathrm{LCH}$ is reported to have an unfavorable prognosis (2).

The authors state that they have no Conflict of Interest (COI).

\section{References}

1. Matsuki E, Tsukada Y, Nakaya A, Yokoyama K, Okamoto S. Successful treatment of adult onset Langerhans cell histiocytosis with multi-drug combination therapy. Intern Med 50: 909-914, 2011.

2. Baumgartner I, von Hochstetter A, Baumert B, Luetolf U, Follath F. Langerhans'-cell histiocytosis in adults. Med Pediatr Oncol 28: 9-14, 1997.

\footnotetext{
(C) 2012 The Japanese Society of Internal Medicine http://www.naika.or.jp/imindex.html
} 